\title{
Harmful micro-algal blooms and local environmental conditions of the coastal fringe: Moroccan Mediterranean coasts as a case study
}

\author{
Ferdaous Sitel $^{1, *}$, Belahcen Rijalebled ${ }^{2}$, and Hassan Er-Raioui ${ }^{1}$ \\ ${ }^{1}$ Laboratoire Environnement, Océanologie et Ressources Naturelles (LEORN), Faculté des Sciences et Techniques de Tanger, Université \\ Abdelmalek Essaâdi Tanger-Tétouan \\ ${ }^{2}$ Laboratoire de Phytoplancton, Institut National de Recherche Halieutique, 90000 Tanger, Morocco
}

\begin{abstract}
The dynamic study of harmful phytoplankton, conducted from June 2013 to May 2014, has tracked the evolution of the microalgae community at four sites located along the Moroccan western Mediterranean coast. 91 species and genera of phytoplankton were identified, 8 of which are recognized as potentially toxic. The genus Pseudo-nitzschia, a diatom known to produce domoic acid, is quite prevalent in all four sites, particularly in spring. The toxic dinoflagellate species detected in our study are Gymnodinium catenatum, Alexandrium sp PSP producers, Prorocentruml Lima, Dinophysis acuminata, D. caudata, D. fortii DSP producer, and Ostreopsis sp known palytoxin producer. The species Gymnodinium catenatum proliferates intensively from $\mathrm{S} 1$ to $\mathrm{S} 3$ in winter and S4 in summer, while Alexandrium sp proliferates mainly during spring and late summer with an exceedance of the threshold. Significant blooms of Dinophysis sp were recorded during the summer at all sites. On the other hand, the abundance of Ostreopsis sp was noted during the spring summer period with low concentrations. Discriminant analysis (DFA) of nutrients, toxic species identifies perfect seasonal discrimination. Winter and fall are characterized by high nutrient inputs, but algal biomass is low. On the contrary, spring and summer are characterized by a depletion of nutrients in the environment following the assimilation of these elements by phytoplankton.
\end{abstract}

\section{Introduction}

Coastal areas, which are heavily subject to anthropogenic pressures, are characterized by harmful algal blooms [1]. These phytoplankton algae can be toxic or even lethal to organisms that feed on them directly or indirectly through accumulation in the marine food chain, or to aquatic life in general through the release of toxic substances into the environment [2]. These toxic algae can cause human poisoning via the food chain. Such phenomena, as well as massive fish kills, have already been observed at various points along Morocco's Mediterranean or Atlantic coasts [3 - 5]. In 1994, 64 cases of poisoning were reported on the Moroccan coast, 23 of which were hospitalized and 4 died following the ingestion of bivalves poisoned by the paralytic toxin PSP [6]. From 1998 to 2007, this type of phycotoxin was detected with varying concentrations in several bivalve species on the Moroccan coast [7 - 10].

In 2002, a spectacular bloom of Gymnodinium catenatum was recorded in autumn at the M'diq site with a concentration of 9240 cells/1 [11].

During the period 2008-2009 off the western Mediterranean coast of Morocco, it was following blooms of Pseudo-nitzschia [12]. In this regard, poisoning was recorded in 1978 in Al-Hoceima following the ingestion of mussels "Mytilus galloprovincialis". The symptoms recorded in patients (amnesia), indicate that it is very likely that the contamination is caused by amnesiac phycotoxins (Domoic Acid).

Several factors have been attributed to variations in specific composition, namely: chemical (nutrients, vitamins), physical (turbulence, light, temperature) and biological (competition, grazing) factors. The ecophysiological diversity associated with the specific richness of phytoplankton populations suggests the existence of an environmental preference for each species. Indeed, phytoplankton dynamics are mainly controlled by local environmental conditions, as well as by the response of populations to their variations [13]. Thus, knowledge of the factors that control the dynamics of phytoplankton communities as a whole would be necessary to understand the mechanisms that promote the development of toxic or harmful phytoplankton populations.

\section{Material and methods}

\subsection{Study area}

The region studied corresponds to the coastal fringe of the western Moroccan Mediterranean from M'diq to Targha. Four sites were studied. It is about: S1 $\left(35^{\circ} 41^{\prime} 646 \mathrm{~N}\right.$ -

\footnotetext{
* Corresponding author: ferdaousitel@gmail.com
} 
$\left.05^{\circ} 19^{\prime} 075 \mathrm{~W}\right), \mathrm{S} 2\left(35^{\circ} 37^{\prime} 193 \mathrm{~N}-05^{\circ} 15^{\prime} 771 \mathrm{~W}\right), \mathrm{S} 3$ $\left(35^{\circ} 26^{\prime} 212 \mathrm{~N}-05^{\circ} 04^{\prime} 295 \mathrm{~W}\right)$ and S4 $\left(35^{\circ} 24^{\prime} 682 \mathrm{~N}\right.$ $05^{\circ} 03^{\prime} 445 \mathrm{~W}$ ) (figure 1) characterized by a privileged geographical and strategic position thanks to its opening on the Mediterranean. It is subject to several pressures and pollution risks. It has an interesting number of seaside resorts and ports with fishing and yachting activities. They receive a significant amount of waste from industrial and urban discharges in addition to that generated by tourism and maritime activities [14]; [15].

The location of sampling sites is conditioned by the public health protection vocation of the INRH (National Institute for Fisheries Research) network, i.e. in the vicinity of shellfish production areas in the coastal domain.

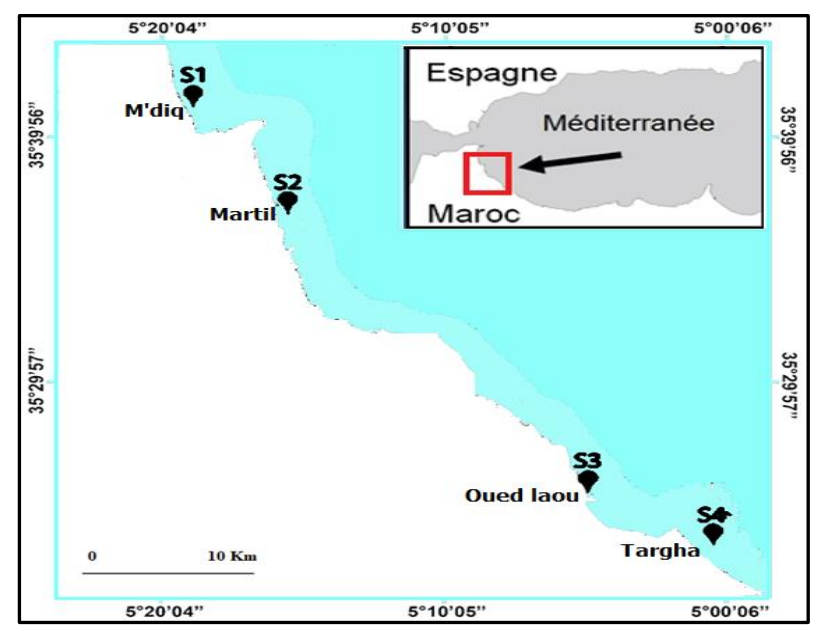

Fig. 1. Geographical location of study sites

\subsection{Sampling and analysis}

Water samples were collected weekly from June 2013 to May 2014 using a Nansen spill bottle. The nonconcentrated samples collected were preserved by the "Lugol" fixative used to preserve phytoplankton. These samples are stirred and then poured into $25 \mathrm{ml}$ sedimentation tanks. The analysis of the tanks is only carried out after a settling time that lasts from 6 hours to one night for most analyses. Observations are made using an inverted LEICA microscopy at 10, 20 and 40x magnification. The tanks are read according to the HASLE method. The systematics of the taxa present and the taxonomic identification of phytoplankton is carried out by reference to several manuals and photographic descriptions. The concentration of phytoplankton species observed is expressed in (cells. $1^{-1}$ ).

For chemical analyses of nutrients and chlorophyll, samples were taken at the surface and taken directly from polyethylene bottles previously washed with $\mathrm{HCl}$ (Merck) about $5 \%(\mathrm{v} / \mathrm{v})$ and rinsed with distilled water, then rinsed two to three times with the water to be analysed and filled to a maximum of $3 / 4$ of their volume. The samples were immediately placed in an isothermal cooler where the temperature is maintained between $2^{\circ}$ and $4^{\circ} \mathrm{C}$, and then sent to the laboratory for further analysis. In parallel, some physico-chemical parameters (temperature) are measured in situ.
For this analysis we used the method of Mullin and Riley [16] adapted by Strickland and Parsons [17] to A.Aminot and Chaussepied [18]. The elements: mineral phosphorus, nitrates, nitrites, ammonium and silicon were determined.

Statistical processing of toxic phytoplankton population data at the four study sites was performed. A discriminant factorial analysis (DFA) using XLSTAT software was used to identify seasonal distributions and describe the main patterns of temporal variability of potentially toxic phytoplankton. A statistical treatment of Spearman correlations between toxic species and nutrients, as well as temperature and chlorophyll, was also performed.

\section{Results}

Inverted microscope observations identified 91 taxa between species and genera in the four study sites. Among these taxa, several potentially toxic species have been identified. The species responsible for paralytic poisoning are Gymnodinium catenatum and Alexandrium sp. The species that produce diarrhoeal toxins are: Prorocentrum lima, Dinophysis caudata, Dinophysis fortii and Dinophysis acuminata. The species known to produce domoic and palytoxin acids belong respectively to the genus Pseudo-nitzschia sp and Ostreopsis sp. The percentage of toxic species equivalent to $29 \%$ remains lower compared to the total number of phytoplankton (Fig. 2).

Gymnodinium catenatum: Exceedances of the normative threshold $\left(1 \times 10^{3}\right.$ cells $\left.1^{-1}\right)$ were recorded during the study period. The maximums recorded are in the order of 1440 cells $1^{-1}$ detected at $S 2$ level during the summer in July, 1760 cells $1^{-1}$ detected during the winter in January to S3, 2000 detected during the spring in May and 5080 cells $\mathrm{1}^{-1}$ detected during the summer in July to S4).

Alexandrium $\mathrm{sp}$ : This genus has been encountered with a maximum that exceeds the normative threshold of $1 \times 10^{3}$ cells $1^{-1}$. It is in the order of 3320 cells $1^{-1}$ recorded during summer at S1, while at other sites, the concentration does not exceed the threshold. The values are 400,240 , and 120 cells $1^{-1}$ measured at S2, S4 and S3 respectively.

Prorocentrum sp : for this genus, no exceedance was recorded throughout the study period. The maximum abundances are of the order of 32600 cells $1^{-1}$ recorded at the S4 level during spring, and of the order of 17640 , 10800 , and 9560 cells $1^{-1}$ recorded at the S1, S3 and S2 levels respectively during summer. Prorocentrum Lima is present at S2 level with a low concentration of $120{\text { cells } 1^{-}}^{-}$ ${ }^{1}$ during the autumn.

Dinophysis sp: Several species of the genus dinophysis have been identified in the study area, namely: Dinophysis caudata, D. acuminata and D. fortii. The most important blooms of this type occur during the summer period with 920 cells $1^{-1}$ to $S 4,880$ cells $1^{-1}$ to $S 1,720$ cells $1^{-1}$ to $S 3$ and 120 cells $1^{-1}$ to $\mathrm{S} 2$. These blooms exceed the normative threshold $\left(4 \times 102\right.$ cells $\left.1^{-1}\right)$. Dinophysis caudata and $D$. acuminata were detected at all sites except S2 with a maximum concentration of 120 cells $\mathrm{1}^{-1}$, recorded in 
autumn at S1 and 80 cells $1^{-1}$,recorded in summer at S3 and in autumn at $\mathrm{S} 4$, while Dinophysis fortii was detected only at S3 (40 cells $\left.1^{-1}\right)$ and S4 (80 cells $\left.1^{-1}\right)$ during spring.

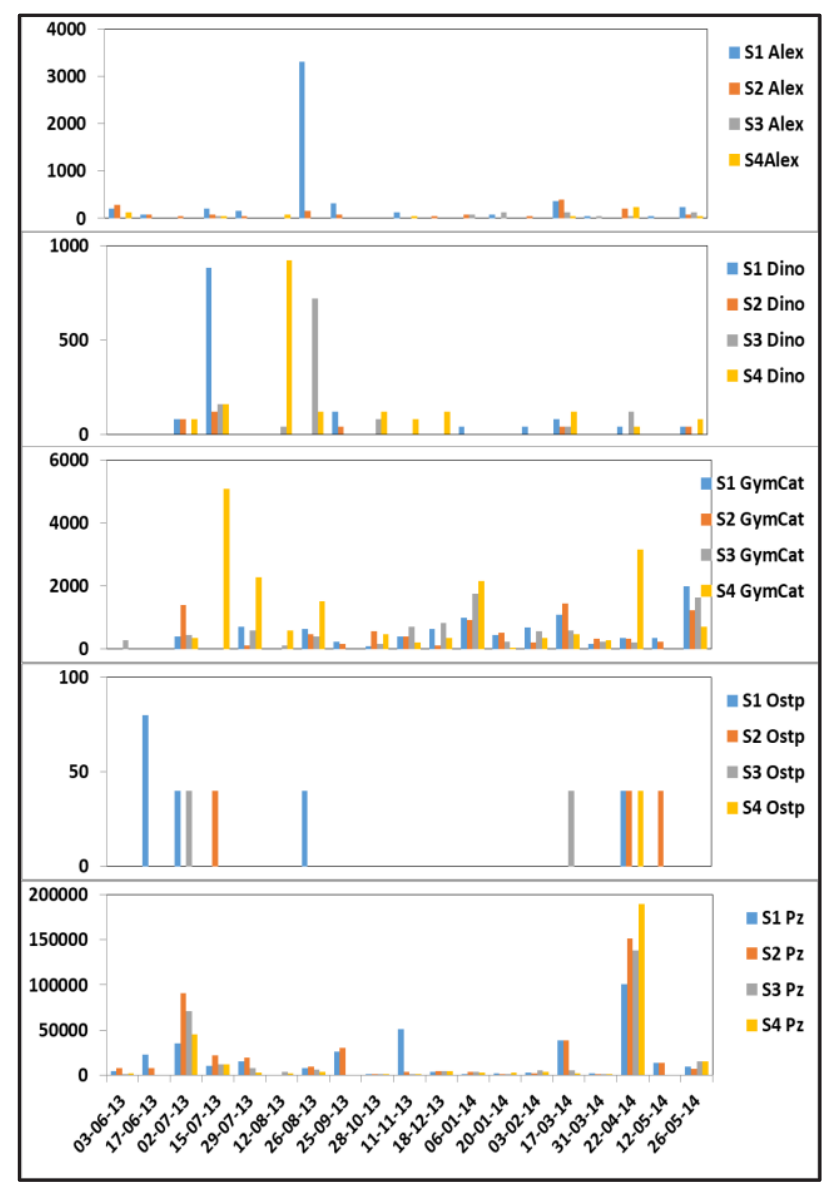

Fig. 2. Evolution of the abundance of potentially toxic species (cell/L) in the waters of S1, S2, S3, and S4

Pseudo-nitzschia sp: this genus is present in all water samples from the four study sites. Exceedances of the normative threshold were detected $\left(1 \times 10^{5}\right.$ cells $\left.1^{-1}\right)$. It was observed in maximum abundance during spring at the $\mathrm{S} 1$ level with 100920 cells $1^{-1}$, equivalent to $47.33 \%$ of phytoplankton, at the S2 level with 151320 cells $1^{-1}$, equivalent to $53.93 \%$ of the total phytoplankton, at the S3 level with 138040 cells $1^{-1}$, equivalent to $59.07 \%$ of the total phytoplankton and at the S4 level with 189960 cells $1^{-1}$, equivalent to $58.31 \%$ of the total phytoplancton.

Ostreopsis sp: the presence of this genus is very sporadic. It was observed only three times at the S1 level with 80 cells $1^{-1}$ as a maximum abundance detected during spring and also at the S2 level with 40 cells $1^{-1}$ as a maximum abundance detected during summer and spring, while at the S4 and S3 level, Ostreopsis sp was observed only once during spring with a value of 40 cells $1^{-1}$.

The results of the chemical analyses of nutrients and Chlorophyll a are shown in Table I and Figure 3 below.

The analytical results for chlorophyll a show average concentrations ranging from 190.85 to $442.37 \mu \mathrm{g} / \mathrm{l}$. The highest levels of chlorophyll a were recorded in summer in August $2013(747.6 \mu \mathrm{g} / \mathrm{l})$ in $\mathrm{S} 1$ and in July (657.23 and $802 \mu \mathrm{g} / \mathrm{l})$ in S2 and S3, in winter in March in S1 and S2 with concentrations of 485.45 and $314.11 \mu \mathrm{g} / \mathrm{l}$ respectively and in spring in April in S3 and S4 with concentrations of 641.4 and $1443.60 \mu \mathrm{g} / \mathrm{l}$ respectively. It is noted that during these periods, massive blooms (Bloom) of certain species that can reach up to $78 \%$ of all phytoplankton in a sample were recorded. Among these species, those that are known to be toxic such as Pseudonitzschia which represents up to 59\% of all phytoplankton in the April sample at S3 level.

The average mineral phosphorus content of the study area is $4 \mu \mathrm{M} / 1$. It varies between $3.65 \mu \mathrm{M} / 1$ recorded at $\mathrm{S} 1$ level and $4.71 \mu \mathrm{M} / 1$ recorded at S4 level (Tab.1). The latter site (S4) has the highest values with three peaks, during spring, summer and winter with values of $9.52 \mu \mathrm{M}$ $/ 1,5.65 \mu \mathrm{M} / 1$ and $5.59 \mu \mathrm{M} / 1$ respectively (Fig. 3).

The average nitrate content is low. It is $1.25 \mu \mathrm{M} / 1$ and ranges from $1.05 \mu \mathrm{M} / 1$ recorded at $\mathrm{S} 2$ to $1.56 \mu \mathrm{M} / 1$ recorded at S3 level (Tab.1). The S1 site has the highest values with 3 remarkable peaks: the first was detected in spring $(3.58 \mu \mathrm{M} / 1)$, the second in late autumn $(2.65 \mu \mathrm{M}$ /1), and the third in early winter $(2.63 \mu \mathrm{M} / 1)$ (Fig. 3).

Table. 1. Range and Average (Mean \pm SDev) of nutritional elements: $\mathrm{PO}_{4}, \mathrm{NO}_{3}, \mathrm{NO}_{2}, \mathrm{NH}_{4}{ }^{+}, \mathrm{Si}$ and Chlorophyll a from $\mathrm{S} 1, \mathrm{~S} 2, \mathrm{~S} 3$ and $\mathrm{S} 4$

\begin{tabular}{|c|c|c|c|c|}
\hline Site & S1 & S2 & S3 & S4 \\
\hline $\begin{array}{r}\text { Chll a } \\
(\mu \mathrm{g} / \mathrm{l})\end{array}$ & $\begin{array}{c}78,53-747,60 \\
190,85 \pm 168,75\end{array}$ & $\begin{array}{c}98,89-657,23 \\
253,46 \pm 134,02\end{array}$ & $\begin{array}{c}133,67-802 \\
310,21 \pm 210,25\end{array}$ & $\begin{array}{l}136,67-1443,6 \\
442,37 \pm 388,99\end{array}$ \\
\hline $\begin{array}{c}\mathrm{NO}_{2} \\
(\mu \mathrm{M} / \mathrm{l})\end{array}$ & $\begin{array}{c}0.84-3.15 \\
1.48 \pm 0.71\end{array}$ & $\begin{array}{l}0.82-3.39 \\
1.62 \pm 0.73\end{array}$ & $\begin{array}{l}0.91-2.24 \\
1.48 \pm 0.56\end{array}$ & $\begin{array}{l}0.87-2.17 \\
1.44 \pm 0.59\end{array}$ \\
\hline $\begin{array}{c}\mathrm{NO}_{3} \\
(\mu \mathrm{M} / \mathrm{l})\end{array}$ & $\begin{array}{c}0.11-3.59 \\
1.15 \pm 1.09\end{array}$ & $\begin{array}{l}0.22-3.35 \\
1.05 \pm 0.95\end{array}$ & $\begin{array}{l}0.41-2.87 \\
1.56 \pm 0.86\end{array}$ & $\begin{array}{c}0.02-3 \\
1.24 \pm 0.92\end{array}$ \\
\hline $\begin{array}{l}\mathrm{NH}_{4}^{+} \\
(\mu \mathrm{M} / \mathrm{l})\end{array}$ & $\begin{array}{l}1.89-17.98 \\
4.02 \pm 4.13\end{array}$ & $\begin{array}{l}1.94-6.97 \\
3.34 \pm 1.69\end{array}$ & $\begin{array}{l}1.99-10.82 \\
3.54 \pm 2.46\end{array}$ & $\begin{array}{c}1.94-8.14 \\
3.22 \pm 1.84\end{array}$ \\
\hline$\underset{(\mu \mathrm{M} / \mathrm{l})}{\mathrm{Si}}$ & $\begin{array}{l}4.62-30.49 \\
7.71 \pm 6.34\end{array}$ & $\begin{array}{l}4.62-7.17 \\
5.88 \pm 0.83\end{array}$ & $\begin{array}{c}2.41-7.39 \\
5.85 \pm 1.7\end{array}$ & $\begin{array}{l}1.53-8.93 \\
5.70 \pm 2.58\end{array}$ \\
\hline $\begin{array}{c}\mathrm{PO}_{4} \\
(\mu \mathrm{M} / \mathrm{l})\end{array}$ & $\begin{array}{c}3.21-5.17 \\
3.65 \pm 0.47\end{array}$ & $\begin{array}{l}3.21-5.29 \\
3.84 \pm 0.63\end{array}$ & $\begin{array}{l}3.09-5.35 \\
3.79 \pm 0.64\end{array}$ & $\begin{array}{l}3.38-9.52 \\
4.71 \pm 1.75\end{array}$ \\
\hline
\end{tabular}

Nitrites have relatively close annual averages: 1.48 $\mu \mathrm{M} / 1$ (at S1 and S3), $1.62 \mu \mathrm{M} / 1$ (at S2) and $1.44 \mu \mathrm{M} / 1$ (at S4) (Tab.1). Sites S1 and S2 have the highest values during winter and spring.

Average ammonium concentrations predominate over other forms of nitrogen throughout the study period. The average ammonium content is $3.55 \mu \mathrm{M} / 1$, and ranges from $3.21 \mu \mathrm{M} / 1$ to $4.02 \mu \mathrm{M} / 1$ (Tab.1). The highest concentrations are found at S1 level $(17.98 \mu \mathrm{M} / 1)$ during the spring period (Fig. 3).

The determined $\mathrm{N} / \mathrm{P}$ ratios can be compared to the REDFIELD ratio $(\mathrm{N} / \mathrm{P}$ at $/$ at $=16$ for vigorous phytoplankton). If the $\mathrm{N} / \mathrm{P}$ ratio is greater than 30 , phosphorus could be depleted first, while a ratio of less than 10 would indicate a potential nitrogen limitation. During the study period, the average annual N / P ratio at the four sites was in the range of 0 to 6 , suggesting a potential nitrogen limitation during the study year.

The average silicon concentration is $6.29 \mu \mathrm{M} / 1$ and varied from $5.7 \mu \mathrm{M} / 1$ to $7.71 \mu \mathrm{M} / 1$ (Tab.1). The highest values were recorded at $\mathrm{S} 1$ level $(30.49 \mu \mathrm{M} / 1)$ during the autumn period, while at the other sites, the silicon content does not exceed $8.93 \mu \mathrm{M} / 1$ (Fig. 3). Statistical processing: 
The Spearman correlation matrix between the analysed elements (nutrient-temperature-chlorophyll a and toxic species shows significantly positive and negative coefficients (Tab. II).

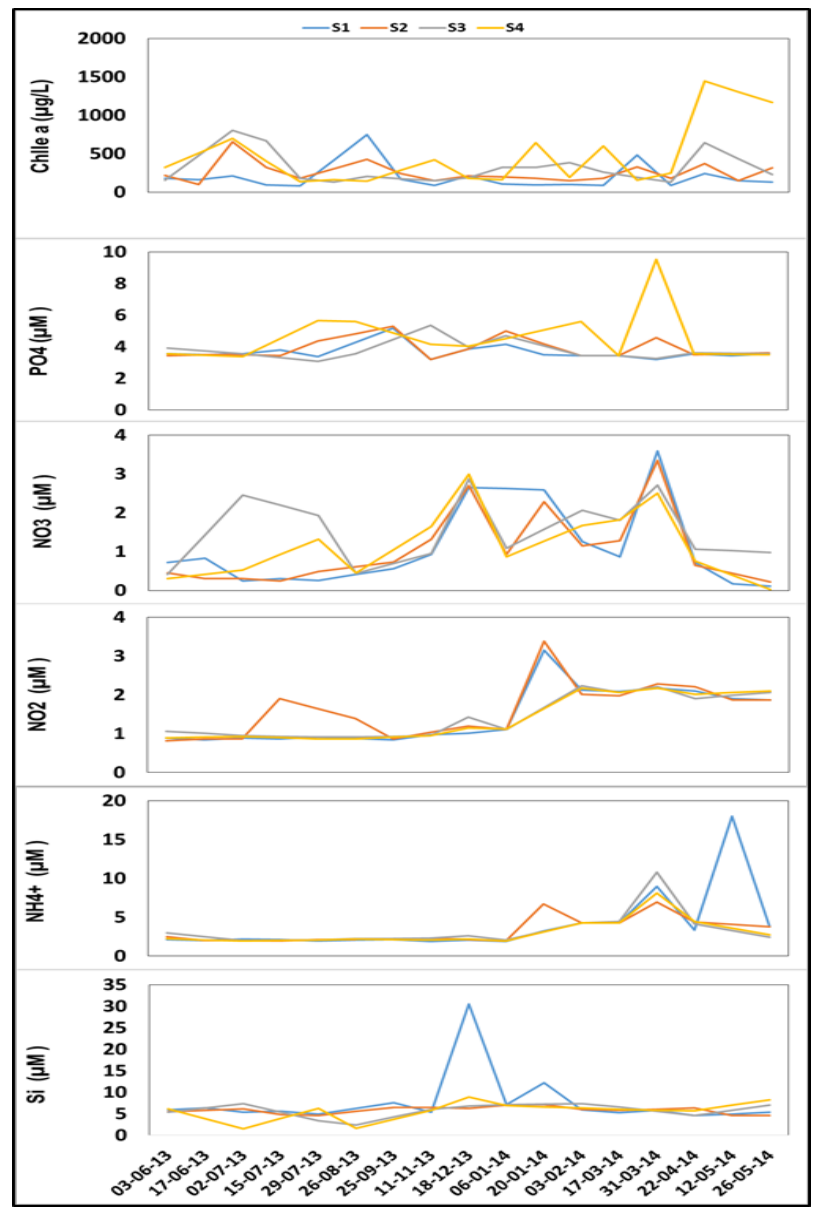

Fig. 3. The evolution of nutrients $\left(\mathrm{PO}_{4}, \mathrm{NO}_{3}, \mathrm{NO}_{2}, \mathrm{NH}_{4}^{+}\right.$et $\left.\mathrm{Si}\right)$ and Chlorophyll a at the four sites

The species Alexandrium sp shows negative correlations with $\mathrm{NO}_{3}$ at $\mathrm{S} 1$ and with $\mathrm{PO}_{4}, \mathrm{NO}_{3}$ and $\mathrm{Si}$ at $\mathrm{S} 4$ and a positive correlation with $\mathrm{NO}_{2}$ at $\mathrm{S} 3$.

Dinophysis sp raises negative correlations with $\mathrm{NO}_{3}$, $\mathrm{SI}, \mathrm{NO}_{2}$ and $\mathrm{Nt}$ at the level of S3 and only with $\mathrm{Si}$ at the level of S2. The positive correlation between this species and the environmental Temperature at S3.

Dinophysis acuminata has only one negative correlation with $\mathrm{NO}_{3}$ at $\mathrm{S} 1$.

Dinophysis fortii shows a high correlation with chllorophyll a and $\mathrm{NH}_{4}+$ at $\mathrm{S} 4$ level and a negative correlation with $\mathrm{PO}_{4}$ and $\mathrm{NO}_{3}$.

Gymnodinium catenatum has only one positive correlation with $\mathrm{Nt}$ at $\mathrm{S} 2$ level.

Ostreopsis sp shows positive correlations with $\mathrm{NH}_{4}+$ at $\mathrm{S} 1$ and $\mathrm{S} 4$ levels.

Pseudo-nitzschia sp shows a strong correlation with Chlorophyll a throughout the study area except S2 . It correlates negatively with $\mathrm{NO}_{3}$ at $\mathrm{S} 1$ and with $\mathrm{Si}$ at $\mathrm{S} 1$ and $\mathrm{S} 2$.

The statistical treatment of the discriminant factor analysis of data collected at the level of the 4 sites shows that the contributions to the total variation of the two axes total $88.93 \%$ in $\mathrm{S} 1,91.4 \%$ in $\mathrm{S} 2,93.38 \%$ in $\mathrm{S} 3$ and 80.65 in S4 (Fig. 4, 5, 6 and 7). We can then distinguish four periods at the level of each site:

Table. 2. Spearman correlation coefficient between the concentration of toxic species, nutrients $\left(\mathrm{PO}_{4}, \mathrm{NO}_{3}, \mathrm{NO}_{2}, \mathrm{NH}_{4}^{+}\right.$ et $\mathrm{Si})$, Chlorophylle a (Chll a) and Temperature $\left(\mathrm{T}^{\circ}\right)$ at the study area level $(\mathrm{p}<0,05)$

\begin{tabular}{|c|c|c|c|c|c|c|c|c|c|}
\hline Esp & Site & $\mathrm{PO}_{4}$ & $\mathrm{NO}_{3}$ & $\mathrm{NO}_{2}$ & $\mathrm{NH}_{4}$ & NT & SI & $\mathbf{T}^{\circ} \mathbf{C}$ & Chll \\
\hline \multirow{4}{*}{ Ostrp } & S1 & $-0,008$ & $-0,244$ & $-0,296$ & $-0,199$ & $-0,358$ & $-0,3$ & 0,325 & 0,576 \\
\hline & S2 & $-0,057$ & $-0,337$ & 0,282 & 0,09 & 0,09 & $-0,068$ & 0,232 & 0,347 \\
\hline & S3 & $-0,223$ & 0,41 & 0,111 & $-0,094$ & 0,251 & 0,094 & $-0,032$ & 0,189 \\
\hline & S4 & $-0,426$ & $-0,344$ & 0,159 & $\mathbf{0 , 5 0 7}$ & 0,185 & $-0,423$ & $-0,067$ & 0,634 \\
\hline \multirow{4}{*}{$\mathbf{P z}$} & S1 & $-0,122$ & $-0,559$ & $-0,308$ & $-0,028$ & $-0,339$ & $-0,61$ & 0,44 & 0,67 \\
\hline & S2 & $-0,341$ & $-0,382$ & $-0,254$ & $-0,282$ & $-0,311$ & $-0,471$ & 0,428 & 0,109 \\
\hline & S3 & $-0,168$ & 0,174 & $-0,045$ & $-0,145$ & 0,032 & $-0,357$ & 0,276 & 0,552 \\
\hline & S4 & $-0,349$ & $-0,218$ & 0,201 & 0,297 & 0,164 & $-0,084$ & 0,112 & 0,593 \\
\hline \multirow{4}{*}{$\begin{array}{l}\text { Gym } \\
\text { cat }\end{array}$} & S1 & $-0,229$ & $-0,17$ & 0,411 & 0,108 & 0,149 & $-0,247$ & $-0,039$ & $-0,011$ \\
\hline & S2 & 0,073 & 0,408 & 0,394 & 0,372 & 0,48 & 0,045 & $-0,299$ & $-0,286$ \\
\hline & S3 & 0,162 & 0,436 & 0,212 & $-0,338$ & 0,07 & 0,33 & $-0,335$ & 0,047 \\
\hline & S4 & $-0,353$ & $-0,018$ & 0,08 & 0,272 & 0,241 & $-0,095$ & 0,371 & 0,334 \\
\hline \multirow{4}{*}{ Alex } & S1 & $-0,218$ & $-0,514$ & $-0,269$ & $-0,07$ & $-0,396$ & $-0,326$ & 0,422 & 0,275 \\
\hline & S2 & $-0,266$ & $-0,218$ & $-0,189$ & $-0,259$ & $-0,183$ & $-0,378$ & 0,041 & $-0,046$ \\
\hline & S3 & $-0,147$ & 0,022 & $\mathbf{0 , 5 3 3}$ & 0,264 & 0,315 & 0,334 & $-0,327$ & 0,288 \\
\hline & S4 & $-0,669$ & $-0,59$ & $-0,066$ & 0,307 & $-0,092$ & $-0,571$ & 0,153 & \\
\hline \multirow{4}{*}{ Dino } & S1 & 0,187 & 0,021 & 0,066 & 0,21 & 0,012 & $-0,171$ & $-0,313$ & 0,179 \\
\hline & S2 & $-0,179$ & $-0,236$ & 0,019 & $-0,214$ & $-0,095$ & $-0,489$ & 0,217 & 0,196 \\
\hline & S3 & $-0,08$ & $-0,555$ & $-0,595$ & $-0,316$ & $-0,632$ & $-0,633$ & $\mathbf{0 , 5 6 6}$ & $-0,048$ \\
\hline & S4 & $-0,094$ & 0,417 & $-0,135$ & $-0,106$ & 0,086 & 0,051 & 0,352 & 0,423 \\
\hline \multirow{4}{*}{$\begin{array}{l}\text { Dino } \\
\text { acu }\end{array}$} & S1 & $-0,015$ & $-0,492$ & 0,159 & 0,203 & 0,029 & $-0,175$ & 0,233 & $-0,058$ \\
\hline & S2 & - & - & - & - & - & - & - & - \\
\hline & S3 & 0,219 & $-0,05$ & 0,174 & 0,359 & 0,221 & $-0,233$ & $-0,11$ & 0,089 \\
\hline & S4 & $-0,142$ & $-0,236$ & 0,047 & $-0,079$ & $-0,11$ & 0,141 & 0,19 & 0,251 \\
\hline \multirow{4}{*}{$\begin{array}{l}\text { Dino } \\
\text { cau }\end{array}$} & S1 & 0,383 & $-0,1$ & $-0,359$ & $-0,06$ & $-0,219$ & 0,26 & 0,341 & 0,1 \\
\hline & S2 & - & - & - & - & - & - & - & - \\
\hline & S3 & $-0,044$ & $-0,303$ & $-0,325$ & $-0,173$ & $-0,346$ & $-0,346$ & 0,304 & $-0,087$ \\
\hline & S4 & 0,095 & 0,094 & $-0,283$ & $-0,222$ & $-0,157$ & $-0,157$ & 0,095 & $-0,063$ \\
\hline \multirow{4}{*}{$\begin{array}{l}\text { Dino } \\
\text { fort }\end{array}$} & S1 & - & - & - & - & - & - & - & - \\
\hline & S2 & - & - & - & - & - & - & - & - \\
\hline & S3 & 0,159 & $-0,11$ & 0,158 & 0,377 & 0,22 & $-0,22$ & $-0,047$ & 0,409 \\
\hline & S4 & 523 & 521 & 84 & & 0 & -0 & 0,048 & \\
\hline
\end{tabular}

Note: Dino acu=Dinophysis acuminata, Dino caud=Dinophysis caudata, Dino=Dinophysis sp, Dino fort=Dinophysis fortii, Alex=Alexandrium sp, S1=M'diq, S2=Corniche martile, S3= Oued laou et S4=Targha.

The spring period:

At the S1 level: it is characterized by: i) the proliferation of Pseudo-nitzschia sp which shows a negative correlation with $\mathrm{Si}$ and $\mathrm{NO}_{3}$, ii) the appearance of Dinophysis acuminata following an enrichment of the medium by $\mathrm{NH}_{4}+$ (the strong correlation with $\mathrm{NH}_{4}^{+}$). It should be noted that these two species have a negative correlation with $\mathrm{NO}_{3}$. iii) the proliferation of Ostreopsis sp (their positive correlation with Pseudo-nitzschia sp).

At the S2 level: it is characterized by: the presence of Alexadrium sp, Pseudonitzschia sp and Ostreopsis sp no correlation has been recorded. At the S3 level: it is characterized by the proliferation of Dinophysis fortii and Alexandrium sp following the enrichment of the medium by the elements $\mathrm{NO}_{2}$ and $\mathrm{NH}_{4}{ }^{+}$. Indeed, the projection of variables (toxic species and nutrients) in the factorial plane (F1 and F2) shows a positive correlation of this period with the concentration of $\mathrm{NH}_{4}{ }^{+}, \mathrm{NO}_{2}, \mathrm{NT}$ and also with the appearance of Dinophysis fotii. It should be noted that this species has a positive correlation with the two species Pseudo-nitzschia sp and Dinophysis acuminata.

S4 level: this period indicates an increase in chlorophyll a and $\mathrm{NH} 4+$ content (positive correlation) and a proliferation of the species Pseudo-nitzschia sp, Alexandrium sp, Dinophysis fortii and Ostreopsis sp, which is attested by the positive correlation between this period and the last three species. As well as a negative correlation between spring and $\mathrm{NO}_{3}$ concentration in the 
environment. It should be noted that there is a negative correlation between the appearance of the species Alexandrium, Dinophysis fortii and the concentration of $\mathrm{PO} 4, \mathrm{NO}_{3}$ and $\mathrm{Si}$, and another positive correlation established between Dinophysis fotii and $\mathrm{NH}_{4}{ }^{+}$.

The summer period:

At the S1 level: it is characterized by the proliferation of Dinophysis sp, and Alexandrium sp There is also a negative correlation between Alexandrium sp and $\mathrm{NO}_{3}$ and between summer and NT content, which demonstrates the depletion of NT medium and in particular $\mathrm{NO}_{3}$.

At the S2 level: it is characterized by a proliferation of Dinophysis sp and Pseudo-nitzschia sp following the decrease in the concentration of $\mathrm{Si}$ and $\mathrm{NO}_{3}$ in the environment, which is attested by the correlation between summer and these 2 species and by the negative correlation between summer and nutrients and by the correlation between these 2 species and the concentration of $\mathrm{NO}_{3}$ and $\mathrm{Si}$.

At the S3 level: it is characterized by the proliferation of Dinophysis sp, Pseudo-nitzschia sp, Dinophysis caudata following the depletion of the medium in $\mathrm{NO}_{2}$ and $\mathrm{NH}_{4}{ }^{+}$(negative correlation in this period and these two elements). A negative correlation exists between Dinophysis sp and $\mathrm{NO}_{3}, \mathrm{NO}_{2}$ and $\mathrm{SI}$ concentrations, as well as a positive correlation between this species and Dinophysis caudata. This period is positively correlated with temperature.

At the S4 level: it is characterized by the intense proliferation of Dinophysis sp and by the appearance of Dinophysis acuminata. The Spearman correlation test shows a positive correlation between summer and Dinophysis sp and another negative correlation between summer and $\mathrm{NH}_{4}{ }^{+}$concentration.

The Autumn period:

At the S1 level: it is distinguished by the appearance of Dinophysis caudata and an enrichment of the environment by $\mathrm{Si}$. It should be noted that there is a positive correlation of this period (fall) with the appearance of Dinophysis caudata and the concentration of Si.

At the level of S3: it is marked by the increase in $\mathrm{PO}_{4}$, which is explained by the correlation between this period and this element.

At the S4 level: it is characterized by the intense proliferation of Dinophysis caudata and by the increase in $\mathrm{NO}_{3}$ concentration in the environment.

The winter period:

At the S1 level: it is characterized by a low temperature (negative correlation of this season with temperature) and by the proliferation of Gymnodinium catenatum. There is also an enrichment of the medium in $\mathrm{NO}_{2}$, which explains the positive correlation between this period and $\mathrm{NO}_{2}$.

At the S2 level: it is characterized by i) the proliferation of Gymnidinium catenatum, ii) a decrease in temperature (negative correlation of winter with temperature) and iii) an increase in $\mathrm{Si}$ (positive correlation of this element with winter).

At the level of S3: it is characterized by a low temperature (negative correlation between this season and temperature) and also the presence of Gymnodinium catenatum.

At the level of S4: it is characterized by high concentrations of $\mathrm{Si}$ and $\mathrm{Nt}$.
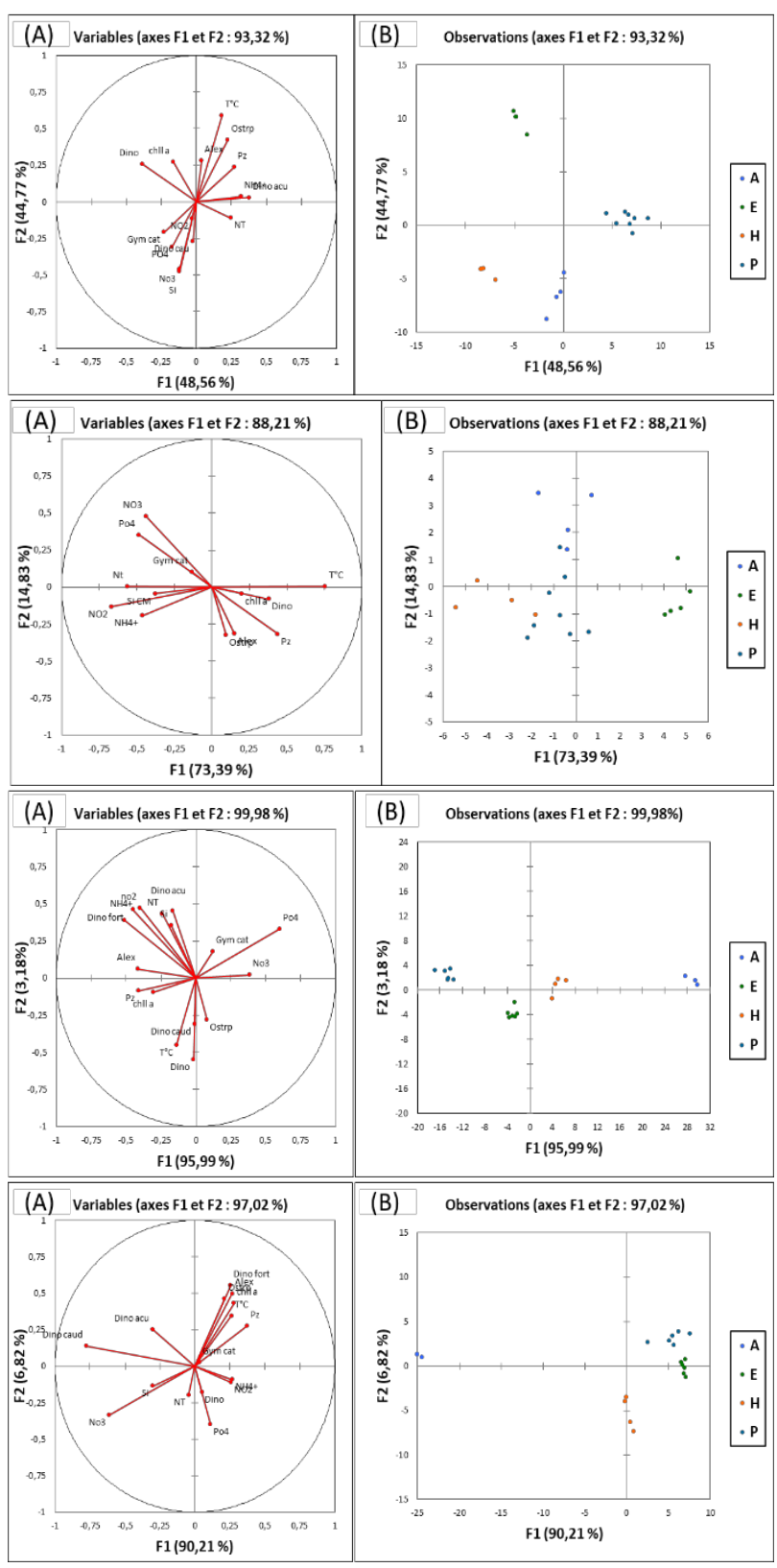

Fig. 4. (A) Projection of variables (toxic species and nutrients) in factorial design F1 and F2), (B) Projection of individuals (sampling dates) in factorial design F1 and F2 at the level of S1,S2,S3 and S4. (A : Automne, E : Eté, H : Hiver, P : Printemps) (Gym cat=Gymnodinium catenatum, $\mathrm{Pz}=$ Pseudonitzschia $\mathrm{sp}$, Dino acu=Dinophysis acuminata, Dino caud=Dinophysis caudata, Dino=Dinophysis $\mathrm{sp}, \quad$ Dino fort=Dinophysis fortii, Alex=Alexandrium $\mathrm{sp}$, Ostrp=Ostriopsis sp, Chll a=Chlorophylle $\mathrm{a}, \mathrm{T}^{\circ} \mathrm{C}=$ Température).

\section{Discussion}

The results of the evolution of mineral phosphorus concentrations reveal that the average value recorded for the entire study area is higher than that reported by Redfield [19] in Mediterranean waters and by Rijal lebled 
[12] on the western Moroccan Mediterranean coast (in M'diq and Oued laou).

At $\mathrm{S} 1$ level, mineral phosphorus inputs are relatively high due to the discharge of untreated domestic effluent from the three main local cities of Sebta, F'nideq and M'diq and also from tourist complexes. On the other hand, M'diq Bay may have a deep water upwelling area. Indeed, the highest phosphorus concentrations are found in upwelling areas of deep waters [20]. While 'at the S2, S3 and S4 levels, mineral phosphorus inputs are relatively higher during the rainy season due to the effect of rainfall input discharges via the wadis, which would be responsible for phosphorus enrichment of the sea. Note that at the $\mathrm{S} 1$ site, the maximum concentrations of mineral phosphorus still do not coincide with periods of heavy rainfall. This suggests that phosphorus may also have a different origin that could be an internal remineralization, such as the existence of a significant amount of detritic organic material. Vacelet [21] provides a possible explanation for the relationship between phytoplankton proliferation and hot weather mineral phosphorus concentrations, the massive release of phosphates by phytoplankton and zooplankton after death.

Nitrates represent the most stable oxidized form of nitrogen in aqueous solution. They enter the nitrogen cycle as the main support for phytoplankton growth. Nitrites are intermediates between nitrates and ammoniacal nitrogen. The latter is essentially the product of the bacterial decomposition of organic compounds [22].

The increase in the content of ammonium, nitrate and nitrite can be explained by the addition of runoff water. On the other hand, a fraction of nitrates and nitrites appear to be produced by the natural process of nitrification by bacteria. Indeed, Boutaib [23] showed the presence of an increase in bacterial activity during the rainy season in M'diq Bay and the Oued Laou estuary. On the other hand, low concentrations of these elements can be explained by the use of these elements during phytoplankton blooms or by the sedimentation process whereby nutrients are recycled between sediments, seaweed and the water column [20]. They are normally trapped by the sediment and then released, depending on the surrounding conditions in the water column and possibly assimilated by phytoplankton.

Revelante and Gilmartin [24] , Berland et al [25], generally consider phosphorus to be the main limiting factor in the Mediterranean, while Becacos-Kontos [26], [27] considers that phosphorus and nitrogen are both limiting in an alternative way. Another author, Vollenweider [28], argues that production in transition areas (sea- land inputs) could be limited by factors other than phosphate and nitrogen that are related to the amount of input received. Balkis [29] notes, in a bay in the Marmara Sea, values below 16 with nitrogen as a limiting factor. Thus, variations in N/P become particularly large as a result of irregular and diverse coastal inputs (riverine inputs, domestic and industrial effluents, precipitation and torrents).

Silicon is necessary for diatom cell growth and is the most important element for the formation of the diatom frustule [30].The average silicon content recorded at S1 level is higher than those recorded at other sites. This difference may be due to the mineralogical variation of the sites. The sediments of M'diq Bay (S1) contain a significant fraction of quartz compared to the sediments of the Oued Laou estuary [31]. In addition to this origin, silicates present in river waters can be of biological origin and come from the dissolution of diatom frustules.

The evolution of the temporal variation of toxic species shows that, at the four sites studied, the variability of these species is subject to a seasonal cycle controlled by environmental parameters.

Dinophysis sp, proliferates intensively during the summer period following the depletion of the environment in $\mathrm{Si}$ and $\mathrm{NO}_{3}$ and $\mathrm{NO}_{2}$. The correlations of these species with these elements at the four study sites are negative). Indeed, Rijal leblad [12], showed that the proliferation of Dinophysis during the summer is consistent with the depletion of $\mathrm{NO}_{3}$ in the environment. Bennouna et al, [32] detected this genus in the waters of the Moroccan Atlantic coast throughout the year precisely in greater density during the summer, during which these waters are characterized by the existence of seasonal coastal upwellings currents. Aubry et al, [33] showed in a study in the Adriatic Sea that the growth of the species $D$. cf. sacculus, D. caudata, D. rotundata, D. fortii and $D$. tripos was independent of nutrient content. Delmas et al, [34] [35] found that there is no relationship between the proliferation of Dinophysis and the availability of dissolved mineral nutrients. These same studies show that this species grows after blooms of Diatoms, in a nutrient depleted environment.

Gymnodinium catenatum is characterized by an abundance during winter following the enrichment of the environment in $\mathrm{NO} 2, \mathrm{PO} 4$, and $\mathrm{Si}$ (positive correlation between this species and these elements). Indeed, Akallal et al, [36] on the North Atlantic coast of Morocco, revealed the detection of Gymnodinium Catenatum in small quantities during spring. On the Atlantic coast, near Casablanca, Tahri Joutei [5] reported the presence of this species especially in early and late summer. TagmoutiTahla [37] detected this organism on the same coast, causing 4 deaths as a result of its proliferation. On the other hand, Rijal leblad [12], found that the species Gymnodinium catenatum has a proliferation preference during autumn and winter following the enrichment of the environment with nutrients.

Alexandrium $\mathrm{sp}$ is characterized by intense proliferation during the spring-summer period following the depletion of $\mathrm{NO}_{3}, \mathrm{PO}_{4}$ and $\mathrm{Si}$ media, which is explained by the negative correlation of this species with these elements. A study carried out on the Moroccan Mediterranean coastal fringe in M'diq showed the proliferation of Alexandrium sp during the spring-summer period [12]. Anderson [38] showed that the development of Alexandrium sp is due to the re-inoculation of cysts, forms of resistance that remain in the sediment during winter, when environmental conditions are favourable. The same author reported that, in the Gulf of Maine, blooms of this species are related to the interaction between coastal currents and river plumes in which phytoplankton find the conditions (nutrients and light) favourable to their development [39]. 
Pseudo-nitzschia sp proliferates intensively during the spring-summer period following the assimilation of elements such as $\mathrm{Si}$ and $\mathrm{NO}_{3}$, which explains the negative correlation of this species with the elements $\mathrm{Si}$ and $\mathrm{NO}_{3}$ and it is noted that there is a positive correlation with $\mathrm{NH}_{4}{ }^{+}$shown the enrichment of medium in $\mathrm{NH}_{4}{ }^{+}$. In this context, Sholin et al, [40] reported that Pseudo-nitzschia efflorescences could be enhanced by silicon-rich freshwater inputs. Thus Pan \& Rao [41] and Parsons \& Dortch [42] note that the massive proliferation of this type has a relationship with eutrophicated or polluted coastal waters. And in the coasts of Goa, Alkawri and Ramaiah [43] showed that the high abundances of Pseudo-nitzschia coincide with the low concentrations of nitrates, phosphates, and silicates in the waters off Chapora. Rijal leblad [12] found that spring and early autumn are the favourable periods for the development of the majority of Pseudo-nitzschia species.

\section{Conclusion}

Throughout the study area, phytoplankton succession and their ecological cycle would be determined by nutrient levels in the environment and by turbulence. In general, intense blooms of toxic phytoplankton species are recorded during periods of nutrient enrichment, although with specific requirements for each species. Phytoplankton concentration during fall and winter is low, note that a bloom of Gymnodinium catenatum was detected during them at S4 level with a value of 2160 cells.$^{-1}$, but this value remains very low compared to the concentration of other species. In addition, phytoplankton concentrations

During summer and spring are very important, where phytoplankton growth is optimal, and during which blooms of Pseudonitzschia sp were detected throughout the study area with values of $10.10^{4}, 15.10^{4}, 14.10^{4}$ and $19.10^{4}$ cells. $^{-1}$ to $\mathrm{S} 1, \mathrm{~S} 2, \mathrm{~S} 3$, and S4 respectively, and a bloom of Gymnodinium catenatum at S4 with a

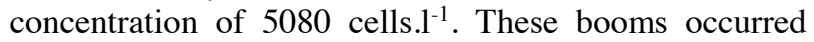
following the enrichment of the environment with nutrients and the turbulence that characterized this period (spring-summer).

Alexandrium spliferates mainly during spring and late summer with an overrun of the threshold. As well as the significant blooms of Dinophysis sp were recorded during the summer when they exceed the threshold at all sites except S2. On the other hand, the abundance of Ostreopsis sp was noted during the spring summer period without exceeding the threshold.

Seasonal variation in environmental parameters in the four ecosystems directly affects the phytoplankton population. In all four ecosystems, phytoplankton population dynamics follow a seasonal pattern.

\section{References}

1. Geohab,. Global Ecology and Oceanography of Harmful Algal Blooms, Science Plan. P. Glibert and G. Pitcher (eds). SCOR and IOC, Baltimore and Paris. Pps. 87 (2001)
2. Aanesen, R.T., Eilersten, H.C., Stabell O.B., Lightinduced toxic properties of the marine alga Phaeocystis pouchetii towards cod larvae. Aquatic Toxicology 40, pp. 109-121 (1998)

3. Beaubrun PC., Les phénomènes d'eaux rouges au Maroc. Rev. Attabea, 32 : 31-35 (1979)

4. Tahri Joutei L., Idrissi, H., Shafée, MS., Berday, N., Etude du phytoplancton toxique sur le littoral méditerranéen de Restinga à Kaasras. Trav. Doc. INRH, 895, 82 pp (1996)

5. Tahri Joutei L.,- Gymnodinium catenatum blooms in Moroccan waters. In : Harmful algae. B. Reguera, J. Blanco, M.L. Fernandez, T. Wyatt (eds), Xunta de Galicia and IOC Unesco, pp : 66-67 (1998)

6. TAGMOUTI F., Etude des phycotoxines marines PSP, DSP chez les mollusques bivalves des côtes marocaines. Mémoire de thèse. Université Hassan II, Faculté des sciences Aïn chock, Casablanca, Maroc. 170p (2001)

7. Taleb, H., Vale, P., Jaime, E. \& Blaghen, M., Study of paralytic shellfish poisoning toxin profile in shellfish from the Mediterranean shore of Morocco. Toxicon 39 (12) : 1855- 1861 (2001)

8. Taleb, H., Vale, P., et Blaghen, M., Spatial and temporal evolution of PSP toxins along the Atlantic shore of Morocco. Toxicon 41 (2) : 199-205. (2003)

9. Sagou R, Amanhir R, Taleb H, Vale P, Blaghen M. \& Loutfi M, Comparative study on differential accumulation of PSP toxins between cockle (Acanthocardia tuberculatum) and sweet clam (Callista chione). Toxicon, 46 (6) 612-8 (2005)

10. Abouabdellah R., Taleb H., Bennouna A., Erler K., Chafik A \& Moukrim A., Paralytic shellfish poisoning toxin profile of mussels Perna perna from southern Atlantic coasts of Morocco. Toxicon, 51 : 780-786 (2008)

11. Rijal Lebled B, Variation spatio-temporelle des espèces phytoplanctoniques réputées toxiques au niveau de la côte Méditerranéenne Occidentale Marocaine (2006)

12. Rijal lebled, B., Variabilité de la contamination des bivalves (Callista chione \& Acanthocardia tuberculata) par les phycotoxines paralysantes (PSP) et amnésiantes (ASP) dans la frange littorale méditerranéenne marocaine: cas de la baie de M'diq et de l'estuaire de Oued Laou. Thèse, Université Abdelmalek Essaadi, 176p (2012)

13. Gailhard, Analyses de la variabilité spatio-temporelle des populations microalgale côtiers observées par le « Réseau de surveillance du phytoplancton et de phycotoxines ». (REPHY) 11,14 p 187 p (2003)

14. Er-Raioui H., Bouzid S., Marhraoui M. and Saliot A., Hydrocarbon pollution of the Mediterranean coastline of Morocco. Ocean and Coastal Management 52, 124 - 129 (2009)

15. Er-raioui H., Khannous S., Ould Mohamed Cheihk M., and Mhamada M., Bouzid S., The Moroccan Mediterranean coastline: A potential threatened by the urban discharges. The Open Environmental Pollution \& Toxicology Journal, 3, 23-36 (2012) 
16. Mullin and Riley, The colorimetric determination of silicate with reference to sea and natural waters. Anal. Chim. Acta, 12, 162-176 (1955)

17. Strickland, J. D. H. and Parsons, T. R., Apractical handbook of sea water analysis. Bull. Fish. Res. Bd. Can. 167. 311p (1972)

18. Aminot A., and Chaussepied M., Manuel des analyses chimiques en milieu marin. Brest, CNEXO, 395p (1983)

19. Redfield A.C., Ketchum B.H. \& Richards, F.A., The influence of organisms on the composition of seawater, p. 26-77. In M. N. Hill [ed.], The sea, Vol. 2. Interscience. (1963)

20. Lacaze J.C., L'eutrophisation des eaux marines et continentales. Book (1996)

21. Vacelet (E.), Rôle des populations phytoplanctoniques et bactériennes dans le cycle du phosphore et de l'azote en mer et dans les flaques supralittorales du golfe de Marseille. Téthys, 1, 1, pp. 5-118 (1969)

22. Tadros, A.B., Hamaida, H.A.E \& Said, T. O., Chemical characteristics of El-Mex fish farm ponds, Egyptian Journal of Aquatic Research, Special Issue, 31: 191-212 (2005)

23. Boutaib R., Qualité microbiologique des gisements coquilliers de la frange littorale méditerrannéenne : F'nideq - Kaa Srass, Période 20032008. Mémoire d'Ingénieur en chef, INRH. 119p (2010)

24. Revelante, N., Gilmartin,, M., The effect of Po river discharge on phytoplankton dynamic in the northern Adriatic Sea. Mar. Biol., 34 : 259-271 (1976)

25. Berland, B.R., Bonin, D. J. \& Maestrini, S. Y., Azote ou phosphore. Considérations sur le« paradoxe nutritionnel » de la mer Meditérranée. Oceanologica Acta, 3(1) :135142 (1980)

26. Becacos-Kontos, T., Saranicos Gulf. In Mediterranean Productivity Project, Technical Report 47, NATO Subcommittee on oceanographic research edited by E. SteemannNielsen, B. Battaglia, H.J. Minas, Copenhagen: 64-78 (1969)

27. Becacos-Kontos, T., Primary production and environmental factors in an oligotrophic biome in the Aegean Sea. Mar. Biol., 42 : 93-98 (1977)

28. Vollenweider R. A., Rinaldi A. et Montanari G., Eutrophication, structure and dynamics of a marine coastal system: results of ten year monitoring along the Emilia-Romagna coast (Northwest Adriatic Sea); in: Marine Coastal Eutrophication. Eds. Vollendweioder R. A., Marchetti R. et Viviani R. : 63 - 106 (1992)

29. Balkis, N., Seasonal variations in the phytoplankton and nutrient dynamics in the neritic water of Büyükçekmece Bay, Sea of Marmara. J. Plank. Res., 25(7): 703-717 (2003)

30. Martin-Jézéquel, V.; Hildebrand, M.; Brzezinski, M.A., Silicon metabolism in diatoms : implications for growth. J. Phycol. 36(5), 821-840 (2000)

31. Benomar Mustapha, Etude de la contamination des côtes ouest de la Mediterannée marocaine par les métaux lourds : Frange littoral de M'diq - Djaoun. Thèse, Université Abdelmalek Assaadi, Faculté des es-sciences Tanger, 220p (2010)
32. Bennouna A., Berland B., El Attar J. \& Assobhei O., Etude des populations phytoplanctoniques de la lagune de Oualidia (Maroc), dinoflagelles potentiellement nuisibles. Marine Life, 10 (1-2) : 318 (2000)

33. Aubry FB, Berton A, Bastianini M, Bertaggia R, Baroni A, Socal G, Seasonal dynamics of Dinophysis in coastal waters of the NW Adriatic Sea (19901996). Bot. Mar., 43 (5): 423-430 (2000)

34. Delmas D, Herbland A, Maestrini SY, Environmental conditions which lead to increase in cell density of the toxic dinoflagellates Dinophysis spp. In nutrientrich and nutrient-poor waters of the French Atlantic coast. Mar. Ecol. Prog. Ser., 89 (1) : 53-61 (1992)

35. Delmas D., Herbland A. et Maestrini S. Y., Do Dinophysis spp. come from the "open sea" along the French Atlantic coast ?; in: Toxic Phytoplankton Blooms in the Sea. Eds. Smayda T. J., Shimizu Y. Elsevier Sci. Publ., New York : 489 -494 (1993)

36. Akallal,R,. Givernaud, T,. Mouradi, A ; Phytoplancton nuisible du littoral atlantique entre Moulay Bousselham et Témara : 288-297 (2003)

37. Tagmouti-tahla F., Chafate H., Fellat-zarrouk K., Talbi M., Blaghen M., Mikou A., Guittet E. Detection of toxins in bivalves on the Moroccan coast. In : Yasumoto T., Oshima Y. \& Fukuyo Y. Harmful and toxic algal blooms, IOC. UNESCO 1996, 85-87 pp.

38. Anderson D. M, Bloom dynamics of toxic Alexandrium species in the northeastern U.S. Limnol. Oceanogr., 42 (5): 1009-1022 (1997)

39. Anderson D. M., The ecology and oceanography of toxic Alexandrium blooms in the Golf of Maine: results from ECOHAB-GOM program. (Abst.) Harmful Algal Blooms, ninth Conference, Tasmania (http://www.utas.edu.au/docs/), 1 p (2000)

40. Sholin, C.A. ; Gulland, F. ; Doucette, G.J.; Benson, S.; Busman, M.; Chavez, F.P.; Cordaro, J.; DeLong, R.; De Vogelaere, A. ; Harvey, J. ; Haulena, M. ; Lefebvre, K. ; Lipscom, T. ; Loscutoff, S. ; Lowenstine, L.J. ; Marin III R. ; Miller P.E. ; McLellan, W.A. ; Moeller, P.D.R. ; Powell, C.R. ; Rowles, T. ; Silvagni, P. ; Silver, M. ; Spraker, T. ; Trainer, V. ; Van Dolah, F.M., Mortality of sea lions along the central California coast linked to a toxic diatom bloom. Nature 403:80-84 (2000)

41. Pan, Y., Subba Rao, D. V., Impacts of Domestic Sewage Effluent on Phytoplankton from Bedford Basin, Eastern Canada .Marine Pollution Bulletin, Vol 34, No. 12, pp. 1001-1005 (1997)

42. Parsons M.L., Dortch Q., Sedimentological evidence of an increase in Pseudo-nitzschia (Bacillariophyceae) abundance in response to coastal eutrophication. Proc. $9^{\text {th }}$ Int. Conf. Harmful algal blooms, February 7-11, Hobart, Tasmania, abstract book, 44 (2000)

43. Alkawri, A.A.S., and N. Ramaiah., Distribution of diatom Pseudo-nitzschia and dinoflagellates of Dinophysis spp along coast off Goa. Journal of Environmental Biology. 32 (1) 65-70 (2011) 